Article

\title{
Effects of Applying Liquid Swine Manure on Soil Quality and Yield Production in Tropical Soybean Crops (Paraná, Brazil)
}

\author{
Valdemir Antoneli ${ }^{1, *(\mathbb{D})}$, Ana Caroline Mosele ${ }^{1}$, João Anésio Bednarz ${ }^{1}$, \\ Manuel Pulido-Fernández ${ }^{2}$ (D) Javier Lozano-Parra ${ }^{3}\left(\mathbb{D}\right.$, Saskia Deborah Keesstra ${ }^{4,5}$ \\ and Jesús Rodrigo-Comino ${ }^{6,7}$ (iD) \\ 1 Department of Geography, Universidade Estadual do Centro-Oeste (UNICENTRO), Irati, P.C. \\ 84500-000 Paraná, Brazil \\ 2 GeoEnvironmental Research Group, Department of Arts and Territory Sciences, University of Extremadura, \\ 10071 Cáceres, Spain \\ 3 Instituto de Geografía, Pontificia Universidad Católica de Chile, Avda. Vicuña Mackenna 4860, \\ Santiago de Chile 7820436, Chile \\ 4 Soil, Water and Land Use Team, Wageningen Environmental Research, Wageningen UR, \\ 6708PB Wageningen, The Netherlands \\ 5 Civil, Surveying and Environmental Engineering, The University of Newcastle, Callaghan 2308, Australia \\ 6 Physical Geography, Trier University, 54286 Trier, Germany \\ 7 Instituto de Geomorfología y Suelos, Department of Geography, University of Málaga, 29071 Málaga, Spain \\ * Correspondence: vaantoneli@gmail.com; Tel.: +55-42-9923-7875
}

Received: 30 May 2019; Accepted: 16 July 2019; Published: 17 July 2019

check for updates

\begin{abstract}
Brazil is one of the main producers of pork meat in the world. It is well-known that the agricultural sector is a key component of the economic development of this country, where super-intensive fields are only competitive in the globalized market. For the farmers, the application of swine manure to fertilize the soil can increase the yearly income, but it also may cause serious environmental problems related to soil health and soil quality. In this research, we assessed the effects of applying liquid swine manure in a tropical soybean (Glycine max) plantation to better understand when this technique stops being effective and starts causing a threat to soil health and quality. Therefore, we compared values of several soil properties and the soybean yield on treated fields at 10 random points belonging to 7 different plots that were treated with the liquid swine manure over a period ranging from 0 to 15 years. The results showed a positive linear trend in soybean production from 2.45 to $3.08 \mathrm{Mg} \mathrm{ha}^{-1} \mathrm{yr}^{-1}$. This positive trend was also recorded for some key soil parameters such as porosity and exchangeable cations content $(\mathrm{Ca}, \mathrm{Mg}, \mathrm{K}$, and $\mathrm{Al})$. Additionally, positive effects were also found for organic matter content after 10 years of application. Our findings suggest that the use of liquid swine manure has a positive effect on soybean yield and improves soil quality, particularly on mixed farms where pigs are intensively raised nearby cultivated fields.
\end{abstract}

Keywords: chronosequence; mixed-farming; agricultural land management; agricultural intensification; fertilization

\section{Introduction}

Humanity will reach around 9 billion people by 2050 [1]. Undoubtedly, this fact will cause a significant increase in food demand for future human consumption [2]. Steinfeld et al. [3] already estimated the increase of landless livestock production systems as a way of guaranteeing enough meat production for an increasingly urban global population. The greatest growth in terms of the number 
of people, and consequently of meat production, would logically occur in developing countries in which high birth rates are still common [4]. Considering the type of food consumed by the population,

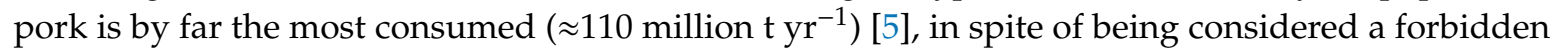
food for Muslims [6] and Jews [7], and a large increase in the number of vegetarians [8].

In 2016, Brazil produced 3.73 million tons of pork, mostly in landless farms, which ranks them in fourth place in the world top statistics after China, the European Union, and the United States [9]. However, this also means a large production of (solid and liquid) manure and other wastes that can be found on an intensive farm [10]. Therefore, Brazil has to face a double challenge in the next few decades: (a) increasing its meat production aimed at feeding local people and maintaining exports, and (b) managing farm manure properly in order to reduce their negative impacts (e.g., water pollution).

Some alternatives have been proposed so far to use swine manure: biogas (methane) production [11], feeding cattle and fish, and soil fertilization. The latter option is currently well accepted. Applying (solid and liquid) swine manure as fertilizer in agricultural areas has been reported to have positive effects on fertility, organic matter content, and crop production [12,13]. The application of manure from other livestock species (e.g., sheep, cattle, etc.) has also been reported to have positive effects [14,15], although, to date, it is still necessary to conduct additional research to analyze the effects of different types of manure under comparable conditions for different chronosequences and crops [16].

For instance, Kafle and Chen [17] compared the biochemical methane potential of the most common types of livestock manure (dairy, horse, goat, chicken, and swine) in order to be able to predict the effect of animals on greenhouse gases (GHG) emissions. Also, Scczech and Smolinska [18] compared different types of livestock manure to assess which type is most effective against plant diseases. Moreover, Meng et al. [19] studied the effects of seven different treatments of vegetal fertilizers (composed of wheat straw, oil cake, and cottonseed cake) on soil quality, crop production, and $\mathrm{N}_{2} \mathrm{O}$ emissions in long-term research $(\approx 15$ years) in China. These kinds of research can be considered a clear start toward developing new policies and strategies to correctly manage soil resources.

On the other hand, negative effects of applying (liquid) manure on agricultural soils have been also observed, which comprise of degradation processes such as (ground) water pollution [20], eutrophication of surface water [21], soil salinization [15], leaching of pollutants [22], and GHG emissions [23]. Although there is a wide consensus in the scientific community on the main cause of these above-mentioned problems, namely mismanagement, a comprehensive study focused on the balance between negative and positive effects of applying manure could be of great value for decision-makers in areas where super-intensive productions are common.

Several (partial) studies focused on the pros and cons of applying manures from different perspectives have been carried out so far in Brazil. Kunz et al. [24] analyzed possible solutions for storing liquid swine manure for a long time in pits or covered ponds. Sigua et al. [25] found the presence of dangerous bacteria at a watershed scale as a consequence of the mismanagement of pig manure and slurry in some farms in the southern State of Santa Catarina. Cherubini et al. [26] compared four different management systems of swine manure (liquid manure storage in slurry tanks, a biodigester by a flare, a biodigester for energy purposes, and composting), although this study did not focus on an agricultural purpose.

Another controversial point, which is currently the most important motivation of this research, is the lack of a consensus in the literature about the efficiency of liquid swine manure (LSM) as an enhancer of soil quality, particularly in terms of its temporal effects, i.e., when do these practices become effective? Is there any time after which it starts to be harmful to soils? There are many studies that have shown an improvement in soil quality after at least 10 years of treatment, e.g., Asada et al. [27] in Japan (13 years); Loss et al. [28] in Brazil (10 years); and Andrade et al. [29] and Rodrigues de Melo et al. [30], also in Brazil (20 years and 9 years with chicken manure, respectively).

Taking into account the above-mentioned, the main goal of this research was to better understand the temporal dynamics (chronosequence) of soil quality assessed by key indicators such as porosity, bulk density, aggregate stability, $\mathrm{pH}$, organic matter, potassium, calcium, magnesium, and aluminum 
(as an indicator of toxicity), and the crop production of soybean, following a temporal gradient (A1-1 year, A2-3 years, A3-5 years, A4-7 years, A5-10 years; A6-15 years; AC: control area without manure). Our hypothesis was that the crop production and soil quality increased until a level of toxicity is reached (perhaps evidenced by $\mathrm{Al}$ content), which could be longer than 15 years.

\section{Materials and Methods}

\subsection{Study Area}

The study was conducted in a privately-owned farm located in the rural municipality of Irati (Paraná State, Brazil): $25^{\circ} 33^{\prime} 12^{\prime \prime} \mathrm{S}$ and $50^{\circ} 52^{\prime} 20^{\prime \prime} \mathrm{W}$. The plots comprised a total area of 29 ha, of which 20 ha were annually cultivated with soybean (Glycine max) crops (harvested once per year due to relatively cold conditions in some months of the year) since 1998 (20-year duration) under a non-tillage system. In winter, oats (Avena strigosa) were sown to function as a vegetation cover during the rainiest period. The remaining 9 ha was divided into (i) an enclosure of 1 ha where pigs were raised, (ii) 4 ha with natural pastures, and (iii) 4 ha with Araucaria forest (Figure 1). This soil management aims to reduce soil erosion and provides biomass for the next cultivation (soybean) cycle.

The agricultural fields ( 20 ha) were divided into seven areas (talhões in Portuguese) with different periods of application of manure and the time when fertilization by manure began (Table 1 and Figure 1). The farm was a traditional faxinal transformed into a more productive mixed-farming system where the swine manure generated within the farm is "recycled" as fertilizer.
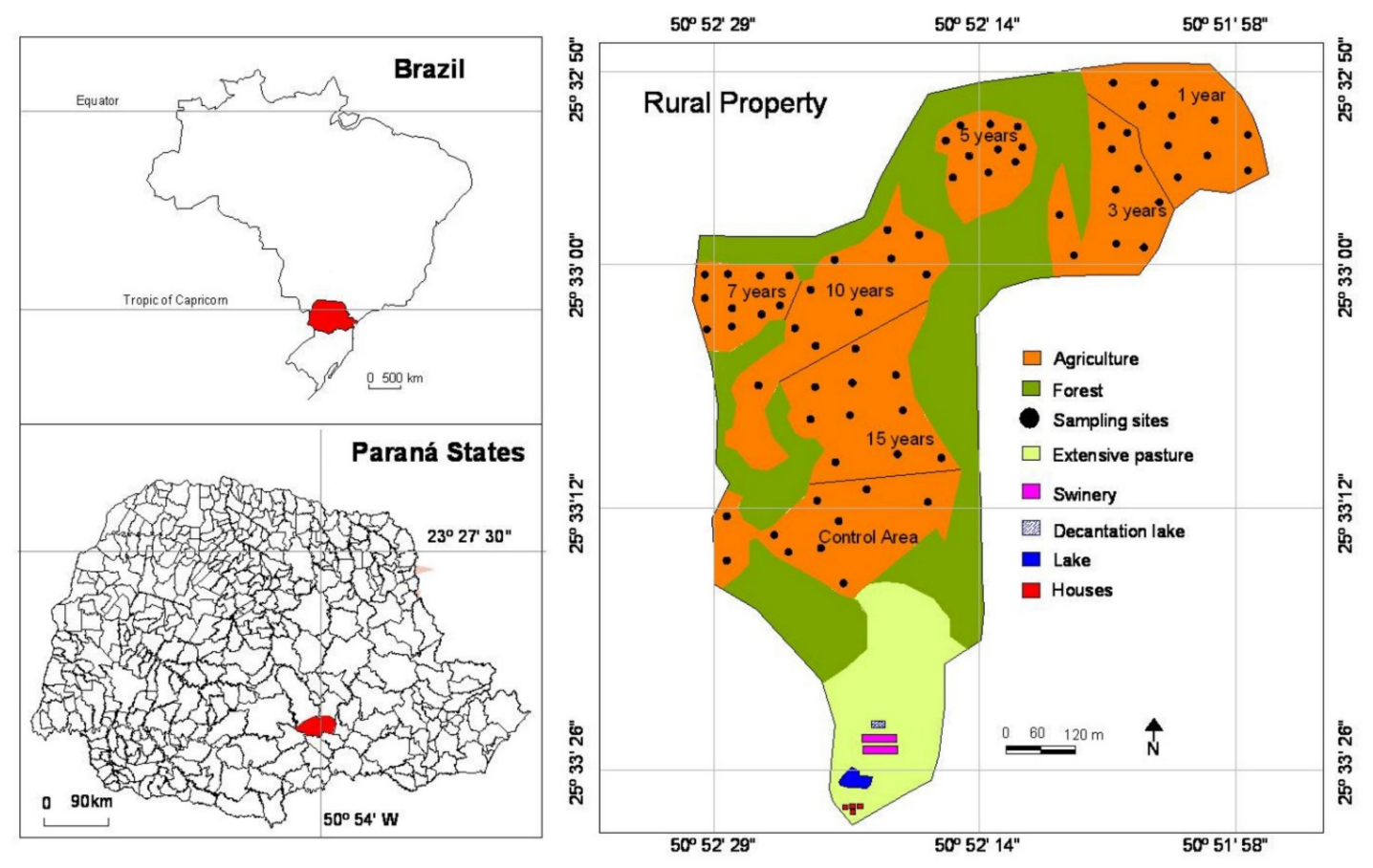

Figure 1. The geographical location of the farm and its seven study areas, including their sampling points.

The farm is located in the sedimentary basin of the Paraná River in the eastern part of the escarpment of the Serra Geral (limit between the second and third Paraná plateaus). The mean elevation is $850 \mathrm{~m}$ a.s.l. and the average slopes are $12 \%$. The dominant soil type is a Cambisol [31], which reaches $88 \%$ of the farmland surface. The climate can be defined as humid subtropical without dry seasons and it freezes in the coldest months. These physical constraints have limited the economic profitability of the farm as a traditional faxinal. For these reasons, the farmer installed some facilities aimed at raising pigs in an intensive system. 
Regarding the livestock production cycle, the animals arrived at the farm facilities (Figure 2a) in the final part of the raising period. They arrived at the age of 60 days and they remained there until reaching 150 days when they left to be slaughtered. Each lot held 680 animals, which generated around $50 \mathrm{~m}^{3}$ of liquid swine manure during their stay in the farm (information provided by the farmer during non-formal interviews). These wastes are stored in a covered pond with a capacity of $100 \mathrm{~m}^{3}$ (Figure 2b), which was spread over the agricultural areas in September (beginning of the soybean cropping season). Finally, the farmer added an average of 5 to $7 \mathrm{~m}^{3}$ of liquid swine manure per hectare.

Table 1. Main characteristics of the study areas (A).

\begin{tabular}{cccccccc}
\hline & AC & A1 & A2 & A3 & A4 & A5 & A6 \\
\hline No. of years of application & 0 & 1 & 3 & 5 & 7 & 10 & 15 \\
Slope (\%) & 13 & 14 & 12 & 10 & 12 & 13 & 9 \\
Sand (\%) & 20 & 22 & 21 & 24 & 21 & 23 & 24 \\
Silt (\%) & 32 & 34 & 33 & 35 & 31 & 33 & 35 \\
Clay (\%) & 48 & 44 & 47 & 41 & 48 & 46 & 41 \\
Time of crops (years) & 15 & 15 & 15 & 17 & 17 & 20 & 20 \\
Surface biomass before crop (ton ha ${ }^{-1}$ ) & 3.8 & 4.1 & 3.8 & 3.5 & 4.1 & 4.0 & 3.9 \\
\hline
\end{tabular}

A1-1 year, A2-3 years, A3-5 years, A4-7 years, A5-10 years; A6-15 years; AC: control area without manure.
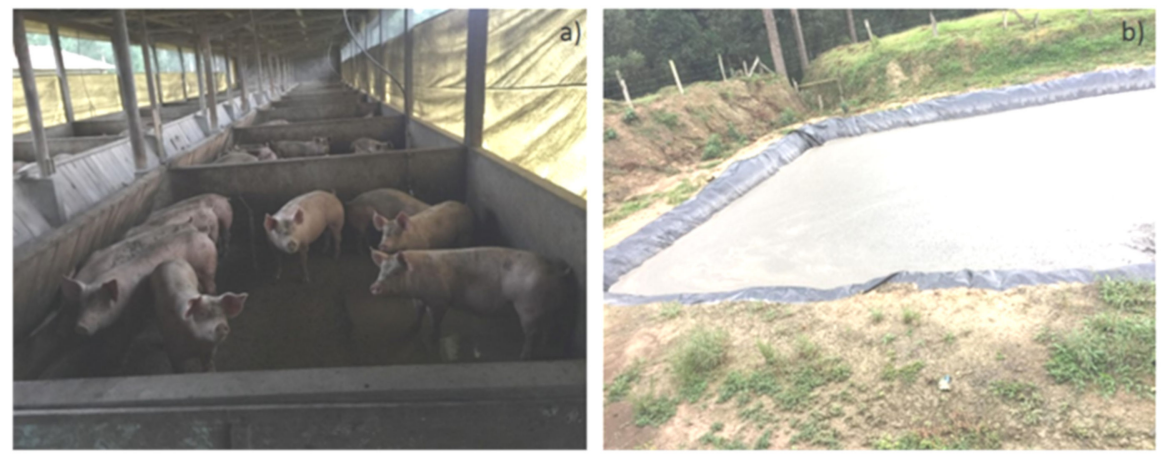

Figure 2. Some pigs on the farm (a) and the covered pond where the liquid manure is stored (b).

\subsection{Soil Sampling and Analysis}

First, the farm was mapped using the software ArcMap 10.5 (ESRI, Redlands, CA, USA) in order to delimitate the different study areas according to the time when fertilization using liquid swine manure was undertaken. Then, a total number of six areas with different timespans of fertilization were identified and another one that had never been fertilized was used as a control area (AC). In every plot, 10 random points were chosen to collect soil samples in order to analyze some key physical and chemical properties. This soil sampling strategy allowed us to assess different environmental conditions at the pedon scale with different inclination, roughness, and antecedent soil moisture in order to see the antecedent soil aptitude prior to being cultivated. Three depth intervals were considered: $0-10 \mathrm{~cm}, 10-20 \mathrm{~cm}$, and $20-30 \mathrm{~cm}$. These soil depths were chosen to assess the soil quality effect in the most superficial layers where soil erosion processes characterized by intense overland flow and sediment yield were more intense.

A total of 30 soil samples were collected in each study plot (210 samples in the whole farm as the input of the dataset). The sampling time was in October 2017 (approximately at the beginning of the soybean cultivation) and after that, the soil samples were transported to the laboratory for standard analysis. The dataset was composed of the 210 cases mentioned above and 10 variables: aggregate stability index, bulk density, soil porosity, $\mathrm{pH}, \mathrm{K}, \mathrm{Ca}, \mathrm{Mg}, \mathrm{Al}, \mathrm{SOM}$ (soil organic matter), and soybean production. The aggregate stability was estimated under wet conditions following the Yoder method [32] described by Kiehl [33], identifying the geometric and weighted mean diameters of each soil sample. With this information, the aggregate stability index could be quantified [34]. 
Bulk density was estimated by using the core method ( $\approx 100 \mathrm{~cm}^{3}$ of volume) [35] and soil porosity with the volumetric balloon method [36]. Chemical properties ( $\mathrm{pH}, \mathrm{K}, \mathrm{Ca}, \mathrm{Mg}$, and $\mathrm{Al}$ ) and soil organic matter were calculated using standard methods of laboratory $[37,38]$. In addition, five samples of liquid swine manure were collected in the covered pond and delivered to the laboratory in order to find its chemical composition. The soybean production was estimated immediately before the beginning of the harvesting. For this estimation, 10 randomly selected micro-plots of $5 \times 5 \mathrm{~m}$ in each study area were used, where soybean plants were cut and sent to the laboratory in order to estimate the production of each plot (expressed in tons ha ${ }^{-1}$ ). The plots were located near the soil sampling points in order to be able to correlate them with each other.

\subsection{Data Analysis}

We worked on the dataset characterized by 210 cases and 10 variables classified in four different steps. The first one was to show the basic statistical parameters such as mean, minimum, maximum, standard deviation, and coefficient of variation of the chemistry of the swine manure and the 10 soil variables considered. It was complemented with an analysis of the temporal trend using a linear graph. Second, a comparison between the mean values of each study area was carried out in order to detect significant differences in the variables. The third task was to conduct a linear correlation analysis (after testing the normality of the variables) between all the variables in order to find possible cause-effect relationships. The most significant correlations were analyzed with more detail using scatterplots and regression analyses. The statistical analyses were carried out by using the software package Statistica 6.0 [39]. The main goal was to assess the values that show the highest relationships among them.

\section{Results}

\subsection{Chemistry of Swine Manure}

Table 2 shows the chemical properties of the liquid swine manure stored in the covered pond. The $\mathrm{pH}$ ranged from 6.40 to 7.30 (neutral values), nitrogen from 2.25 to $3.10 \mathrm{~g} \mathrm{~L}^{-1}$, phosphorous from 2.58 to $3.41 \mathrm{~g} \mathrm{~L}^{-1}$, manganese from 0.03 to $0.04 \mathrm{~g} \mathrm{~L}^{-1}$, copper from 0.06 to $0.08 \mathrm{~g} \mathrm{~L}^{-1}$, organic carbon from 15.70 to $17.10 \mathrm{~g} \mathrm{~L}^{-1}$, and potassium from 1.07 to $1.31 \mathrm{~g} \mathrm{~L}^{-1}$, showing a low data variability $(\mathrm{CV} \leq 15 \%)$. The $\mathrm{pH}$ values were negatively correlated with organic carbon $(\mathrm{r}=-0.900, p<0.05)$ and copper $(r=-0.949, p<0.05)$. In addition, organic carbon showed a significant correlation with potassium $(\mathrm{r}=-0.900, p<0.05)$.

Table 2. Mean values (expressed in $\mathrm{g} \mathrm{L}^{-1}$ ) of the samples of collected liquid swine manure.

\begin{tabular}{cccccccc}
\hline & $\mathbf{p H}$ & $\mathbf{N}$ & $\mathbf{P}$ & $\mathbf{M n}$ & $\mathbf{C u}$ & $\mathbf{O C}$ & $\mathbf{K}$ \\
\hline Sample 1 & 6.80 & 2.25 & 2.97 & 0.04 & 0.07 & 16.40 & 1.25 \\
Sample 2 & 6.40 & 2.78 & 2.58 & 0.04 & 0.08 & 19.70 & 1.07 \\
Sample 3 & 7.30 & 3.10 & 3.15 & 0.04 & 0.06 & 15.70 & 1.31 \\
Sample 4 & 6.90 & 2.29 & 3.27 & 0.03 & 0.06 & 16.50 & 1.17 \\
Sample 5 & 6.50 & 2.27 & 3.41 & 0.04 & 0.08 & 17.10 & 1.21 \\
Average & 6.78 & 2.54 & 3.08 & 0.04 & 0.07 & 17.08 & 1.20 \\
Standard deviation & 0.36 & 0.38 & 0.32 & 0.00 & 0.01 & 1.55 & 0.09 \\
Coefficient of variation (\%) & 5.26 & 15.14 & 10.43 & 12.82 & 11.96 & 9.06 & 7.50 \\
\hline
\end{tabular}

\subsection{Soil Properties}

The mean values of each soil property studied for all depth intervals and years of treatments are shown in Table 3. When looking at the changes over time (the temporal pattern, which was significant according to the Kruskal-Wallis test) of increasing values were found for every property, except bulk density, which showed a decreasing trend. For the spatial pattern, we found a reduction in values of 
every variable with increasing depth. Nevertheless, some remarkable differences between variables were found when comparing different years of treatment and depth.

Table 3. Mean values of soil properties. ASI: aggregate stability index; BD: bulk density $\left(\mathrm{g} \mathrm{cm}^{-3}\right)$; $\mathrm{K}$, $\mathrm{Ca}, \mathrm{Mg}$, and $\mathrm{Al}$ are expressed in cmolc $\mathrm{dm}^{-3}$; $\mathrm{SOM}$ in $\mathrm{g} \mathrm{kg}^{-1}$, and soybean yield in tons $\mathrm{ha}^{-1}$.

\begin{tabular}{|c|c|c|c|c|c|c|c|c|c|c|}
\hline Years of Treatment & Depth $(\mathrm{cm})$ & ASI & BD & Porosity & K & $\mathrm{Ca}$ & $\mathrm{Mg}$ & Al & SOM & Yield \\
\hline \multirow{3}{*}{0} & $0-10$ & 52.01 & 1.38 & 42.74 & 0.38 & 1.67 & 1.52 & 0.92 & 38.80 & \multirow{3}{*}{2.46} \\
\hline & $10-20$ & 51.85 & 1.37 & 42.47 & 0.37 & 0.89 & 1.39 & 0.81 & 27.57 & \\
\hline & $20-30$ & 51.30 & 1.38 & 42.90 & 0.28 & 0.83 & 1.23 & 1.01 & 21.96 & \\
\hline \multirow{3}{*}{1} & $0-10$ & 52.81 & 1.37 & 44.05 & 0.42 & 1.91 & 2.01 & 1.49 & 38.92 & \multirow{3}{*}{2.45} \\
\hline & $10-20$ & 51.60 & 1.36 & 45.09 & 0.39 & 1.01 & 1.54 & 2.00 & 32.22 & \\
\hline & $20-30$ & 50.64 & 1.36 & 43.16 & 0.29 & 0.81 & 1.28 & 2.33 & 22.86 & \\
\hline \multirow{3}{*}{3} & $0-10$ & 54.48 & 1.24 & 50.82 & 0.69 & 2.34 & 2.96 & 1.59 & 41.71 & \multirow{3}{*}{2.54} \\
\hline & $10-20$ & 52.76 & 1.25 & 48.82 & 0.48 & 2.00 & 1.81 & 1.99 & 35.51 & \\
\hline & $20-30$ & 51.75 & 1.29 & 47.31 & 0.34 & 1.65 & 1.45 & 2.13 & 29.34 & \\
\hline \multirow{3}{*}{5} & $0-10$ & 60.44 & 1.22 & 53.99 & 0.80 & 3.89 & 3.06 & 1.95 & 42.91 & \multirow{3}{*}{2.66} \\
\hline & $10-20$ & 55.64 & 1.24 & 53.89 & 0.55 & 2.73 & 1.65 & 2.09 & 38.29 & \\
\hline & $20-30$ & 52.84 & 1.29 & 53.72 & 0.39 & 2.09 & 1.33 & 2.22 & 31.47 & \\
\hline \multirow{3}{*}{7} & $0-10$ & 61.62 & 1.22 & 55.60 & 1.11 & 5.09 & 6.16 & 2.68 & 43.96 & \multirow{3}{*}{2.75} \\
\hline & $10-20$ & 57.50 & 1.23 & 54.63 & 0.78 & 3.79 & 4.62 & 3.26 & 42.74 & \\
\hline & $20-30$ & 54.27 & 1.25 & 53.67 & 0.48 & 2.83 & 3.12 & 3.39 & 36.00 & \\
\hline \multirow{3}{*}{10} & $0-10$ & 64.71 & 1.19 & 60.97 & 1.37 & 7.18 & 10.74 & 4.92 & 45.34 & \multirow{3}{*}{2.84} \\
\hline & $10-20$ & 59.95 & 1.20 & 59.44 & 1.02 & 4.90 & 9.64 & 5.60 & 44.61 & \\
\hline & $20-30$ & 57.13 & 1.21 & 58.67 & 0.90 & 4.00 & 7.85 & 7.02 & 42.87 & \\
\hline \multirow{3}{*}{15} & $0-10$ & 65.46 & 1.18 & 63.20 & 2.19 & 7.81 & 12.36 & 6.80 & 45.92 & \multirow{3}{*}{3.08} \\
\hline & $10-20$ & 64.52 & 1.19 & 62.37 & 1.17 & 6.60 & 10.34 & 7.31 & 45.69 & \\
\hline & $20-30$ & 63.37 & 1.20 & 61.73 & 0.98 & 5.59 & 8.44 & 8.74 & 43.94 & \\
\hline
\end{tabular}

The effects of the treatment were significant from a statistical point of view after 5 to 7 years of treatment at every depth. However, this trend was not found for the aggregate stability index at the depth interval of $20-30 \mathrm{~cm}$ (10 years). With respect to soil depth, only the aggregate stability showed significant differences between depth intervals after 5,7 , and 10 years of treatment. The analyzed chemical and biological properties showed significant differences between depth intervals in all the periods but the tendency was only significantly different between $0-10 \mathrm{~cm}$ and $20-30 \mathrm{~cm}$ after 5 (Al), 7 (SOM), $10(\mathrm{Mg})$, and 15 years $(\mathrm{Ca})$ of treatment. Potassium showed significant differences between all the intervals after 3 years of treatment.

At the surface $(0-10 \mathrm{~cm})$, all the variables (except bulk density) increased their mean values over time. The aggregate stability index increased for each year of treatment by 0.90 , porosity by $1.4 \%, \mathrm{~K}$ by $0.12 \mathrm{cmolc} \mathrm{dm}^{-3}$, Ca by $0.41 \mathrm{cmolc} \mathrm{dm}^{-3}, \mathrm{Mg} 0.72$ by cmolc dm${ }^{-3}$, Al by $0.39 \mathrm{cmolc} \mathrm{dm}^{-3}$, and soil organic matter by $0.47 \mathrm{~g} \mathrm{~kg}^{-1}$. From 10 to $20 \mathrm{~cm}$ depth, the trend was similar but the amount of increase per year decreased, with the exception of $\mathrm{Al}$ and SOM that increased by $0.43 \mathrm{cmolc} \mathrm{dm}^{-3}$ $\mathrm{yr}^{-1}$ and $1.21 \mathrm{~g} \mathrm{~kg}^{-1} \mathrm{yr}^{-1}$, respectively. In the deepest soil layer $(20-30 \mathrm{~cm})$, the temporal pattern was very similar to the $10-20 \mathrm{~cm}$ soil layer, with a general increment of all variables and lower increasing values per year. However, $\mathrm{Al}$ showed an increase of $0.52 \mathrm{cmolc} \mathrm{dm}^{-3} \mathrm{yr}^{-1}$ and SOM of $1.47 \mathrm{~g} \mathrm{~kg} \mathrm{yr}^{-1}$. Therefore, these results prove the capacity of the deepest soil layer to store, at least, more $\mathrm{Al}$ and SOM.

\subsection{Correlation and Regression Analysis}

Table 4 shows the coefficient of correlation between the different variables of the dataset. Most of them showed a very high correlation (significant at $p<0.001$ ), which shows how the time of treatment and its consequent improvement of soil quality were positively influencing the soybean production.

Figure 3 shows the scatterplot of potassium content (for the three depth intervals) against soybean yield, which alongside calcium, helped to influence the soybean production. The first interval $(0-10 \mathrm{~cm})$ showed an $R^{2}$ value of 0.98 , the second one $(10-20 \mathrm{~cm}$ ) reached 0.95 , and the deepest one 0.87 . 
From these results, we consider that soybean production can depend on the number of soil nutrients that can be stored in the whole profile, and not only at the surface level.

Table 4. Coefficients of correlation between variables ( $N=210$, Spearman). ASI: aggregate stability index; BD: bulk density. ${ }^{*}, * *$, and ${ }^{* * *}$ mean statistical significance at $p<0.05, p<0.01$, and $p<0.001$, respectively.

\begin{tabular}{|c|c|c|c|c|c|c|c|c|c|c|}
\hline & Time & Depth & ASI & BD & Por & K & $\mathrm{Ca}$ & $\mathrm{Mg}$ & Al & SOM \\
\hline Depth & 0.000 & & & & & & & & & \\
\hline ASI & $0.822 * * *$ & $-0.326^{* * *}$ & & & & & & & & \\
\hline BD & $-0.857^{* * *}$ & $0.169 *$ & $-0.773^{* * *}$ & & & & & & & \\
\hline K & $0.861^{* * *}$ & $-0.429^{* * *}$ & $0.854^{* * *}$ & $-0.836^{* * *}$ & $0.843^{* * *}$ & & & & & \\
\hline $\mathrm{Ca}$ & $0.920 * * *$ & $-0.316^{* * *}$ & $0.861^{* * *}$ & $-0.848^{* * *}$ & $0.900^{* * * *}$ & $0.949^{* * *}$ & & & & \\
\hline $\mathrm{Mg}$ & $0.864^{* * *}$ & $-0.345^{* * *}$ & $0.822^{* * *}$ & $-0.796^{* * *}$ & $0.824^{* * *}$ & $0.918^{* * *}$ & $0.910 * * *$ & & & \\
\hline SOM & $0.808^{* * * *}$ & $-0.498^{* * *}$ & $0.843^{* * *}$ & $-0.774^{* * *}$ & $0.787^{* * *}$ & $0.923^{* * *}$ & $0.906^{* * * *}$ & $0.907^{* * *}$ & $0.649^{* * *}$ & \\
\hline Yield & $0.936 * * *$ & 0.000 & $0.800^{* * *}$ & $-0.818^{* * *}$ & $0.845^{* * *}$ & $0.817^{* * *}$ & $0.868^{* * *}$ & $0.803^{* * * *}$ & $0.854^{* * *}$ & $0.757^{* * *}$ \\
\hline
\end{tabular}

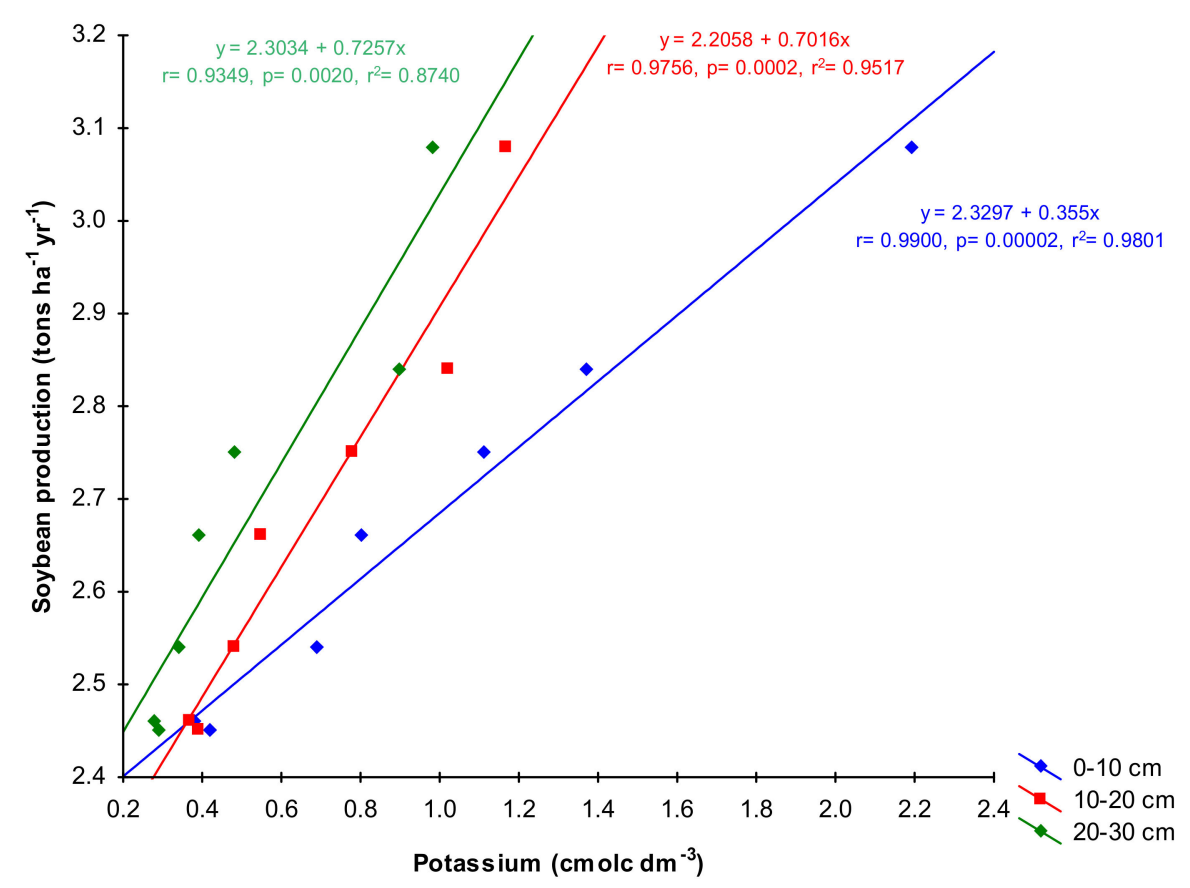

Figure 3. Scatterplot of potassium content at three depths vs. soybean production.

\section{Discussion}

The survival of many farmers of the central region of the Paraná State (Southern Brazil) depends on finding strategies that allow for optimizing the economic performance of the land since the traditional faxinal system (extensive ranching) is now vanishing due to its lack of profitability [40]. One of the strategies followed by the owner of the studied farm was to convert a former faxinal farm into a mixed-farming system where one part of the farm $(\approx 25 \%)$ was dedicated to livestock husbandry (60 days outside +90 days inside). The remaining land surface was annually cultivated soybean crops of relatively high profitability. This formula allowed the owner to save much more money in fertilizers since they can produce a large volume of manure each year, and in transport costs because he does not need to buy and transport fertilizers.

The positive effects of applying liquid swine manure in tropical soybean crops have been confirmed by our research, which demonstrated a positive trend in crop production and improvement in soil quality (physical, chemical, and biological properties), at least in the first 15 years of application. We have to remark that we considered only the upper layers of the soil where soil erosion processes are more intense. Future research is needed to assess the impacts of manure application on soil depths of more than $30 \mathrm{~cm}$. Possibly, sub-surface flow movements, water content, and microbiology are also 
modified due to the application of manure and the intensification of the production. Therefore, we must still be careful with interpreting these positive effects in the upper layers of the soils because some soil properties, such as the amount of $\mathrm{Al}$, increased [41].

Soil samples were collected at the beginning of the soybean cultivation. Soil variables were measured prior to cultivation (i.e., prior to manure application) and used for the correlation analysis to detect possible cause-effect relationships between soil variables and the soybean yield. This off-set in sampling time for both parameters may have introduced some uncertainties in the results as the soil fertility status, and hence yield, may have been impacted by the applied manure. In our study, the Al content reached $8.74 \mathrm{cmolc} \mathrm{dm}^{-3}$ in the deepest part of the soils $(20-30 \mathrm{~cm})$, which made it, together with bulk density, the only variables that increased their values with increasing depth. Furthermore, this formula may also only be suitable for tropical areas where the process of decomposition of organic matter is usually quite fast [42] but dryer environments may lead to an excess of nitrogen [43]. For instance, the research carried out by Mellek et al. [44] shows the positive effects of applying (dairy) liquid manure for only two years in a farm located in the Paraná State (Southern Brazil). They oppose the opinion of many other scientists who consider the application of liquid manure a non-sustainable soil management practice due to its negative effects leading to water pollution. In this way, for instance, Bakhsh et al. [45] investigated the $\mathrm{NO}_{3}-\mathrm{N}$ into shallow groundwater in a study carried out in Iowa (USA). Also, Tabbara [46] confirmed the potential loss of phosphorous only 24 hours after applying the manure. In this matter, the accumulation of $\mathrm{Al}$ in the $20-30 \mathrm{~cm}$ depth layer can perhaps be interpreted as a risk of storing toxic elements that can be infiltrated into the groundwater or transported to the land surface through surface runoff and erosion.

Regarding the application of liquid manure on soybean crops, Schmidt et al. [47] considered this an acceptable management, except when a disease may be present in the soil. In this research, the authors worked on farms where the white mold (Sclerotinia sclerotiorum (lib.) d. By.) disease had been present in the past. Another management question is the necessity of immediate rainfall after the application of manure. Under the current and predicted climate change, vulnerable areas around the world are likely to receive more and more erratic rainfall, which will increase soil vulnerability [48-50]. However, since this factor cannot be controlled, it is important to develop effective strategies to mitigate soil quality issues. On the other hand, the loss of the effectiveness of the treatment and the possibilities of toxic elements to end up in the water drainage increase considerably [51]. In this tropical area, where the study was conducted, the temporal rainfall pattern is quite regular at the moment, but it can be risky in the case of the effects of climate change or El Niño/La Niña (ENSO/ENOS) that will reduce the number of days of rainfall.

Another controversial question we will face in the future is the emissions of $\mathrm{N}_{2} \mathrm{O}$ and $\mathrm{CH}_{4}$ during the composting of liquid swine manure [52] that can be reduced with the proper use of cover in the slurry ponds. In the case of the European Union, the normative (Corrigendum to Commission Implementing Decision (EU) 2017/302 of 15 February 2017 establishing best available techniques (BAT) conclusions, under Directive 2010/75/EU of the European Parliament and of the Council, for the intensive rearing of poultry or pigs) to manage this kind of facilities is quite strict. In Brazil, the consciousness is now increasing regarding the problems mismanagement of liquid manure can cause for the environment. However, as other authors demonstrated for other study areas, the intensification of the land use changes and the introduction of new cultivars could add new variables to these kinds of studies [52].

\section{Conclusions}

The positive effects of applying liquid swine manure in tropical soybean crops have been confirmed for at least the first 15 years of treatment. Therefore, it could be a sustainable strategy for many farmers that need to increase the profitability of their farms without damaging the environment. This practice considerably improved soil properties from the first year of treatment onwards, and significant differences were found even after only five years of application. This enhancement in soil quality had positive effects in terms of soybean production, which increased by $0.65 \mathrm{tha}^{-1}$. We conclude that it was 
particularly interesting to note the evolution of $\mathrm{Ca}$ and $\mathrm{K}$ in the whole soil profile, which were highly correlated with soybean production. It is also remarkable that an accumulation of a toxic element such as $\mathrm{Al}$ was found, although it was only measured at a depth of $20-30 \mathrm{~cm}$. Therefore, further research should focus on the impacts of the manure application from the $30 \mathrm{~cm}$ soil depth downwards.

Author Contributions: Conceptualization, V.A., A.C.M., and J.A.B.; methodology, V.A., A.C.M., and J.A.B.; validation, V.A., A.C.M., and J.A.B.; formal analysis, M.P.-F. and J.L.-P.; writing-original draft preparation, M.P.-F., J.L.-P., S.D.K., and J.R.-C.; writing-review and editing, M.P.-F., J.L.-P., S.D.K., and J.R.-C.; supervision, V.A.

Funding: This research received no external funding.

Acknowledgments: We thank the farmer Alcelmo Waselechen for making his farm available for research to be carried out.

Conflicts of Interest: The authors declare no conflict of interest.

\section{References}

1. Tripathi, A.D.; Mishra, R.; Maurya, K.K.; Singh, R.B.; Wilson, D.W. Estimates for World Population and Global Food Availability for Global Health. In The Role of Functional Food Security in Global Health; Elsevier: Amsterdam, The Netherlands, 2019; pp. 3-24.

2. Godfray, H.C.J.; Beddington, J.R.; Crute, I.R.; Haddad, L.; Lawrence, D.; Muir, J.F.; Pretty, J.; Robinson, S.; Thomas, S.M.; Toulmin, C. Food security: The challenge of feeding 9 billion people. Science 2010, 327, 812-818. [CrossRef] [PubMed]

3. Steinfeld, H.; Gerber, P.; Wassenaar, T.; Castel, V.; de Haan, C. Livestock's Long Shadow: Environmental Issues and Options; Food \& Agriculture Organization: Rome, Italy, 2006; p. 390.

4. Stolnitz, G.J. The demographic transition: From high to low birth rates and death rates. In Population Growth; Routledge: Abingdon, UK, 2017; pp. 30-46.

5. Errecart, V.; Lucero, M.; Sosa, M. Análisis del mercado mundial de carnes; Facultad de Economía y Negocios, Universidad Nacional de San Martín: Tarapoto, Perú, 2015.

6. Ali, M.E.; Razzak, M.A.; Hamid, S.B.A.; Rahman, M.M.; Al Amin, M.; Rashid, N.R.A. Multiplex PCR assay for the detection of five meat species forbidden in Islamic foods. Food Chem. 2015, 177, 214-224. [CrossRef] [PubMed]

7. Dugan, B. Religion and food service. Cornell Hotel Restaur. Adm. Q. 1994, 35, 80-85. [CrossRef]

8. Leitzmann, C. Vegetarian nutrition: Past, present, future. Am. J. Clin. Nutr. 2014, 100, 496S-502S. [CrossRef] [PubMed]

9. De Souza, H.C.; de Almeida Fehr, L.C.F.; de Souza Trindade, J.A.; Tavares, M.; Custos de produção de suínos: Estudo nos principais estados produtores do Brasil. Anais do Congresso Brasileiro de Custos-ABC. 2018. Available online: https://anaiscbc.emnuvens.com.br/anais/article/view/4476 (accessed on 17 July 2019).

10. Sá, M.; Aita, C.; Doneda, A.; Pujol, S.; Cantú, R.; Jacques, I.; Bastiani, G.; Oliveira, P.; Lopes, P. Dinâmica da população de coliformes durante a compostagem automatizada de dejetos líquidos de suínos. Arq. Bras. Med. Vet. Zootec. 2014, 66, 1197-1206. [CrossRef]

11. Marinho Mathias, J.F.C. Manure as a resource: Livestock waste management from anaerobic digestion, opportunities and challenges for Brazil. Int. Food Agribus. Manag. Rev. 2014, 17, 87-110.

12. Hountin, J.; Karam, A.; Couillard, D.; Cescas, M. Use of a fractionation procedure to assess the potential for P movement in a soil profile after 14 years of liquid pig manure fertilization. Agric. Ecosyst. Environ. 2000, 78, 77-84. [CrossRef]

13. Scherer, E.E.; Baldissera, I.T.; Nesi, C.N. Propriedades químicas de um Latossolo Vermelho sob plantio direto e adubação com esterco de suínos. Revista Brasileira de Ciência do Solo 2007, 31, 123-131. [CrossRef]

14. Mhlontlo, S.; Muchaonyerwa, P.; Mnkeni, P. Effects of sheep kraal manure on growth, dry matter yield and leaf nutrient composition of a local amaranthus accession in the central region of the Eastern Cape Province, South Africa. Water SA 2007, 33, 363-368. [CrossRef]

15. Hao, X.; Chang, C. Does long-term heavy cattle manure application increase salinity of a clay loam soil in semi-arid southern Alberta? Ecosyst. Environ. 2003, 94, 89-103. [CrossRef] 
16. De Cesare Barbosa, G.M.; de Oliveira, J.F.; Miyazawa, M.; Ruiz, D.B.; Tavares Filho, J. Aggregation and clay dispersion of an oxisol treated with swine and poultry manures. Soil Tillage Res. 2015, 146, 279-285. [CrossRef]

17. Kafle, G.K.; Chen, L. Comparison on batch anaerobic digestion of five different livestock manures and prediction of biochemical methane potential (BMP) using different statistical models. Waste Manag. 2016, 48, 492-502. [CrossRef] [PubMed]

18. Szczech, M.; Smolińska, U. Comparison of suppressiveness of vermicomposts produced from animal manures and sewage sludge against Phytophthora nicotianae Breda de Haan var. nicotianae. J. Phytopathol. 2001, 149, 77-82. [CrossRef]

19. Meng, L.; Ding, W.; Cai, Z. Long-term application of organic manure and nitrogen fertilizer on N2O emissions, soil quality and crop production in a sandy loam soil. Soil Biol. Biochem. 2005, 37, 2037-2045. [CrossRef]

20. Qian, X.; Shen, G.; Wang, Z.; Zhang, X.; Hong, Z. Effect of swine liquid manure application in paddy field on water quality, soil fertility and crop yields. Paddy Water Environ. 2018, 16, 15-22. [CrossRef]

21. Mawdsley, J.L.; Bardgett, R.D.; Merry, R.J.; Pain, B.F.; Theodorou, M.K. Pathogens in livestock waste, their potential for movement through soil and environmental pollution. Appl. Soil Ecol. 1995, 2, 1-15. [CrossRef]

22. Amin, M.M.; Forslund, A.; Bui, X.T.; Juhler, R.K.; Petersen, S.O.; Lægdsmand, M. Persistence and leaching potential of microorganisms and mineral $\mathrm{N}$ in animal manure applied to intact soil columns. Appl. Environ. Microbiol. 2013, 79, 535-542. [CrossRef] [PubMed]

23. Westerman, P.; Bicudo, J. Management considerations for organic waste use in agriculture. Bioresour. Technol. 2005, 96, 215-221. [CrossRef] [PubMed]

24. Kunz, A.; Miele, M.; Steinmetz, R. Advanced swine manure treatment and utilization in Brazil. Bioresour. Technol. 2009, 100, 5485-5489. [CrossRef]

25. Sigua, G.C.; Palhares, J.C.P.; Kich, J.D.; Mulinari, M.R.; Mattei, R.M.; Klein, J.B.; Muller, S.; Plieske, G. Microbiological quality assessment of watershed associated with animal-based agriculture in Santa Catarina, Brazil. Water Air Soil Pollut. 2010, 210, 307-316. [CrossRef]

26. Cherubini, E.; Zanghelini, G.M.; Alvarenga, R.A.F.; Franco, D.; Soares, S.R. Life cycle assessment of swine production in Brazil: A comparison of four manure management systems. J. Clean. Prod. 2015, 87, 68-77. [CrossRef]

27. Asada, K.; Yabushita, Y.; Saito, H.; Nishimura, T. Effect of long-term swine-manure application on soil hydraulic properties and heavy metal behaviour. Eur. J. Soil Sci. 2012, 63, 368-376. [CrossRef]

28. Loss, A.; Lourenzi, C.R.; dos Santos Junior, E.; Junior, C.A.M.; Benedet, L.; Pereira, M.G.; de Cássia Piccolo, M.; Brunetto, G.; Lovato, P.E.; Comin, J.J. Carbon, nitrogen and natural abundance of 13C and 15N in biogenic and physicogenic aggregates in a soil with 10 years of pig manure application. Soil Tillage Res. 2017, 166, 52-58. [CrossRef]

29. Andrade, A.P.; Rauber, L.P.; Mafra, Á.L.; Baretta, D.; Rosa, M.G.d.; Friederichs, A.; Mafra, M.S.H.; Casara, A.C. Changes in physical properties and organic carbon of a Kandiudox fertilized with manure. Ciência Rural 2016, 46, 809-814. [CrossRef]

30. De Melo, T.R.; Pereira, M.G.; de Cesare Barbosa, G.M.; da Silva Neto, E.C.; Andrello, A.C.; Tavares Filho, J. Biogenic aggregation intensifies soil improvement caused by manures. Soil Tillage Res. 2019, 190, 186-193. [CrossRef]

31. IUSS Working Group WRB. World Reference Base for Soil Resources 2014, Update 2015. International Soil Classification System for Naming Soils and Creating Legends for Soil Maps; World Soil Resources Reports No. 106; FAO: Rome, Italy, 2015; p. 203.

32. Yoder, R.E. A direct method of aggregate analysis of soils, and a study of the physical nature of erosion losses. J. Am. Soc. Agron. 1936, 28, 337-351. [CrossRef]

33. Kiehl, E. Manual de edafologia: Relação solo-planta; Ceres: Piracicaba, Brazil, 1979; p. 262.

34. Kemper, W.D. Aggregate stability. In Methods of Soil Analysis; Black, C.A., Ed.; American Society of Agronomy: Madison, WI, USA, 1965; pp. 499-510.

35. Coile, T.S. Soil samplers. Soil Sci. 1936, 42, 139-142. [CrossRef]

36. Donagema, G.K.; de Campos, D.B.; Calderano, S.B.; Teixeira, W.; Viana, J.M. Manual de métodos de análise de solo. In Embrapa Solos-Documentos (INFOTECA-E); EMBRAPA: Brasilia, Brazil, 2011.

37. MAPA. Métodos oficiales de análisis: Suelos y aguas; Ministerio de Agricultura, Pesca y Alimentación, Dirección General de Politica Alimentaria: Madrid, Spain, 1982; p. 182. 
38. Walkley, A.; Black, L.A. An examination of Degtjareff method for determining soil organic matter and a proposed modification of the chromic acid titration method. Soil Sci. 1934, 37, 29-38. [CrossRef]

39. Statsoft. STATISTICA (Data Analysis Software System), Version 6; Statsoft: Tulsa, OK, USA, 2001.

40. Antoneli, V.; Rebinski, E.; Bednarz, J.; Rodrigo-Comino, J.; Keesstra, S.; Cerdà, A.; Pulido Fernández, M. Soil erosion induced by the introduction of new pasture species in a faxinal farm of southern Brazil. Geosciences 2018, 8, 166. [CrossRef]

41. Rout, G.; Samantaray, S.; Das, P. Aluminium toxicity in plants: A review. Agronomie 2001, 21, 3-21. [CrossRef]

42. Zech, W.; Senesi, N.; Guggenberger, G.; Kaiser, K.; Lehmann, J.; Miano, T.M.; Miltner, A.; Schroth, G. Factors controlling humification and mineralization of soil organic matter in the tropics. Geoderma 1997, 79, 117-161. [CrossRef]

43. Chang, C.; Janzen, H. Long-term fate of nitrogen from annual feedlot manure applications. J. Environ. Qual. 1996, 25, 785-790. [CrossRef]

44. Mellek, J.E.; Dieckow, J.; Da Silva, V.L.; Favaretto, N.; Pauletti, V.; Vezzani, F.M.; De Souza, J.L.M. Dairy liquid manure and no-tillage: Physical and hydraulic properties and carbon stocks in a Cambisol of Southern Brazil. Soil Tillage Res. 2010, 110, 69-76. [CrossRef]

45. Bakhsh, A.; Kanwar, R.S.; Karlen, D.L. Effects of liquid swine manure applications on NO3-N leaching losses to subsurface drainage water from loamy soils in Iowa. Agric. Ecosyst. Environ. 2005, 109, 118-128. [CrossRef]

46. Tabbara, H. Phosphorus loss to runoff water twenty-four hours after application of liquid swine manure or fertilizer. J. Environ. Qual. 2003, 32, 1044-1052. [CrossRef] [PubMed]

47. Schmidt, J.P.; Lamb, J.A.; Schmitt, M.A.; Randall, G.W.; Orf, J.H.; Gollany, H.T. Soybean varietal response to liquid swine manure application. Agron. J. 2001, 93, 358-363. [CrossRef]

48. Adams, R.M.; Chen, C.C.; McCarl, B.A.; Schimmelpfennig, D.E. Climate variability and climate change: Implications for agriculture. In The Long-Term Economics of Climate Change: Beyond a Doubling of Greenhouse Gas Concentrations; Emerald Group Publishing Limited: Bingley, UK, 2001; pp. 95-113.

49. Akter, T.; Quevauviller, P.; Eisenreich, S.J.; Vaes, G. Impacts of climate and land use changes on flood risk management for the Schijn River, Belgium. Environ. Sci. Policy 2018, 89, 163-175. [CrossRef]

50. Drabo, A. Climate change mitigation and agricultural development models: Primary commodity exports or local consumption production? Ecol. Econ. 2017, 137, 110-125. [CrossRef]

51. Allen, B.L.; Mallarino, A.P. Effect of liquid swine manure rate, incorporation, and timing of rainfall on phosphorus loss with surface runoff. J. Environ. Qual. 2008, 37, 125-137. [CrossRef]

52. Thompson, A.; Wagner-Riddle, C.; Fleming, R. Emissions of $\mathrm{N}_{2} \mathrm{O}$ and $\mathrm{CH}_{4}$ during the composting of liquid swine manure. Environ. Monit. Assess. 2004, 91, 87-104. [CrossRef]

(C) 2019 by the authors. Licensee MDPI, Basel, Switzerland. This article is an open access article distributed under the terms and conditions of the Creative Commons Attribution (CC BY) license (http://creativecommons.org/licenses/by/4.0/). 